University of South Carolina

Scholar Commons

2007

\title{
Accelerated Testing Method for PEM Fuel Cell based Uninterrupted Power Supply Systems
}

Xinyu Huang

University of South Carolina - Columbia, xyhuang@sc.edu

Xiaofeng Wang

Follow this and additional works at: https://scholarcommons.sc.edu/eche_facpub

Part of the Electro-Mechanical Systems Commons, Energy Systems Commons, and the Other Chemical Engineering Commons

\section{Publication Info}

Postprint version. Published in ECS Meeting Abstracts, Issue 596, 2007.

(C) ECS Meeting Abstracts, 2007, The Electrochemical Society Huang, X., Wang, X. (2007). Accelerated Testing Method for PEM Fuel Cell based Uninterrupted Power Supply Systems. ECS Meeting Abstracts, 596.

This Article is brought to you by the Chemical Engineering, Department of at Scholar Commons. It has been accepted for inclusion in Faculty Publications by an authorized administrator of Scholar Commons. For more information, please contact digres@mailbox.sc.edu. 
Accelerated Testing Method for PEM Fuel Cell based Uninterrupted Power Supply Systems

\author{
Xinyu Huang, Xiaofeng Wang \\ Connecticut Global Fuel Cell Center \\ University of Connecticut \\ 44 Weaver Rd, Storrs, CT 06269
}

Proton exchange membrane fuel cell based power systems are on the verge of commercialization for a number of niche applications where batteries are traditionally used. Uninterrupted power supply (UPS) for wireless communication towers and broadband network relay utilities is one of the targeted application of fuel cell power systems with capacity ranging from one to serveral kilowatts. It is believed that fuel cell based UPS systems can offer considerable advantage when extended backup time is desirable. In order to replace the well-known battery based UPS systems, the reliability and perofrmance of fuel cell based UPS system need to be thoroughly evaluated by preferrably independent testing laboratories. Accelerated testing is frequently needed in light of the time constraints in typical product development cycles.

In partnership with Connecticut Innovation, the Connecticut Global Fuel Cell Center at University of Connecticut has established a fuel cell based UPS testing and evaluation facility which provide comprehensive $3^{\text {rd- }}$ party testing and evaluation services for commercial or near-commercial stage fuel cell based UPS systems. Custom accelerated testing protocols are designed to evaluate three main UPS performance metrics: (1) start up reliability; (2) load following capability; (3) and fuel efficiency. In the start-up reliability test, fuel cell based UPS systems are subjected repeated start up and shutdown cyces. In between the cycles, selected PEM fuel cell systems are sujbected to enviornmental conditions that simulate long idling periods. The startup time and success start up rates are recorded to gauge the start up performance. In the load following test, the fuel cell based UPS system is subjected to load transient from one constant level to another. Hydrogen consumption rates are monitored during start up, load following, and constant load to evaluate an overall fuel efficiency under typical UPS usage patterns.

The testing protocols have been applied to a commercial UPS system with a Ballard Nexa power module, and a near-commercial UTC Power PureCell 5 system. The authors report the rationale of accelerated testing protocols as well as the testing results and discussions of performance characteristics for above fuel cell based UPS systems. 